\title{
On the Construction of Political Value System Model of Military Civilian in the New Era
}

\author{
Fang Hua, Liu Wenjuan, Li Meng, Wang Zhengyin, Pan Jian, Yi Kang
}

College of Information and Communication, National University of Defense Technology

\begin{abstract}
This article attempts to discuss the construction of the political value system model of military civilian personnel in the new era from the four dimensions of connotation, construction method, construction principle, and basic structure. From the political standpoint, political attitude, political participation and other dimensions, the scientific connotation of the political values of military civilian personnel in the new era was sorted out; from the aspects of insisting on the nature of the people's army, embodying the functions of the people's army, the particularity of occupation, and the measurability of the people's army, this paper puts forward the principles of constructing the political value system model of the army civilian personnel in the new era. The political value system model of military civilian personnel in the new era is constructed by using the PDU model extraction method and the literature and statistics method.
\end{abstract}

Key Words: civilian personnel; political values; model construction

\section{INTRODUCTION}

To study the political values of military civilian personnel in the new era, a complete content system model is the premise and foundation. Marx once said that any science can only be called a science when it is successfully applied to mathematics. At the same time, everything is composed of many interrelated and mutually restrictive aspects. A single dimension, however important, does not tell the whole story. To grasp the nature and law of things, we must build a series of scientific indicator system from the top down and from the core to the outside, which not only reflects its characteristics qualitatively but also quantitatively. In order to construct the model of military civilian personnel's political value system in the new era, it is necessary to grasp the connotative structure, principles, methods and frame structure of military civilian personnel's political value system on the whole, so as to fully understand and master the cultivation requirements of military civilian personnel's political value system in the new era.

\section{CONNOTATION ANALYSIS OF MILITARY CIVILIAN PERSONNEL'S POLITICAL VALUES IN THE NEW ERA}

Political values generally refer to the social members' views on the political world and the resulting values of the political subject, which is the subjective reflection of the political subject to the political object [1]. The political values of military civilian personnel in the new era refer to the basic concepts and views of military civilian personnel in the new era on the current social and political system and political life, as well as the basic evaluation and behavioral value orientation of political ideals. How to construct the political values of military civilian personnel in the new era is a major practical issue that the military personnel construction cannot avoid. Structurally, the political values mainly should include perceptions of current political system, to the attitude of the ruling party, the understanding of professional political demands, views on the relationship between the individual and collective four dimensions, combined with the particularity of the professional group civilian personnel. The political values of civilian military personnel in the new era should be constructed from the following four aspects: "firm faith, obedience to the party's command, fighting for the army, dedication and dedication".

\subsection{Firm faith is the internal premise of military civilian personnel's political values}

To realize the great rejuvenation of the Chinese nation, China cannot do without the firm faith of every Chinese descendant, including military civilian personnel. President $\mathrm{Xi}$ pointed out that it is the fundamental task of the ideological and political construction of our party and army to firmly believe in Marxism and socialism and communism. ${ }^{i}$ Therefore, the focus of the army's ideological and political work is to establish the correct belief, and to strengthen the spiritual support of military personnel.

In the basic view of the current political system, military civilian personnel should be firm in their beliefs. This is the inherent requirement of military political attribute to military civilian personnel at the level of values. This requires all civilian personnel to continuously strengthen theoretical learning, continue to transform the subjective world and the objective world, and finally achieve a complete understanding and thorough support of the 
existing political system. At all times, we will strengthen our belief in Marxism, the lofty ideal of communism and the common ideal of socialism with Chinese characteristics, be a firm supporter and practitioner of the path of socialism with Chinese characteristics.

\subsection{Following the command of the Party is the essential requirement of the military civilian personnel's political values}

The most important criterion for military personnel construction is political qualification. Civilian personnel are an important part of modern military human resources. They are mainly engaged in non-combat technical and managerial positions in the armed forces. They are of a special nature and have major responsibilities and missions. For this army, political qualification means ensuring eternal obedience to the party. Only by firmly following the party can we ensure the correct political direction for military building and development, ensure the long-term consolidation of the party's ruling position, and ensure that the cause of socialism with Chinese characteristics is prosperous and has a bright future.

In terms of their emotional identification with the ruling party, military civilian personnel should follow the party's command and consciously resist the strategic attempts of hostile western forces to " differentiation" and " westernization" China more consciously and more firmly than other professionals in the society. Civilian military personnel should take a clear stand to refute the absurd views of "non-party and non-political military" and "nationalization of military", firmly uphold a series of systems and principles of the party's absolute leadership over the military, constantly consolidate the ideological foundation of loyalty to the party, and resolutely fulfill the tasks entrusted to them by the party and the people.

\subsection{Making a strong fight for war is the internal motivation of military civilian personnel's political values}

President $\mathrm{Xi}$ once stressed that the responsibility of strengthening the armed forces has historically fallen on our shoulders [2]. To shoulder this burden, we must have the courage to do so. This is not only the expectation of the party and the people, but also the political character of all military personnel. For the army, the dream of a strong country is the dream of a strong army. It is the duty and mission of every military personnel to make a strong army fight. It guides the efforts of military civilian personnel and is a powerful answer to how to realize political values. Practice has proved that only by persisting in strengthening the armed forces for war can we solve the fundamental problems of how to make military civilian personnel politically qualified and how to serve them well, thus can take the initiative to integrate the personal ideal into the great practice of strengthening and revitalizing the army, and consciously attach importance to the interests of national defense and military construction, so as to realize the personal political ambition and ideal in the process of training and serving the army.

On the basis of correctly understanding the special political requirements of occupation, it is necessary to educate military civilian personnel to understand and grasp the themes of national defense and military construction, to faithfully carry out the missions and tasks entrusted to the army by the party and the people for the new era and strengthen education in the spirit of combat. Through the post to sharpen training, let civilian personnel understand the law and characteristics of informativeness war, take the initiative to study business skills, operate the hand equipment skilfully, in accordance with the requirements of the era of fighting for a strong army, planning the path of personal career development, with a strong sense of enterprise and responsibility into the journey of a strong army.

\subsection{Professional dedication is the moral requirement of military civilian personnel's political values}

Our army is a strong and politically conscious leader under the party of the party. In order to fulfill the mission of the party and the people, all military personnel must always be consistent in the central center of the party in political, ideological and action, always loyal to the party, loyal to the people, and loyal to socialism. For the interests of the party, the state and the people, the duties and the selfless dedication should conscientiously be fulfilled. This kind of dedicated dedication is more important than the other professions in the society, and it is not only a matter of practice, but also the unconditional transformation of active service and urgent task. Thus, dedicated dedication is the political character that the military civilian personnel must have in the camp.

The ideological foundation of military civilian dedication in the new era is based on a correct understanding of the relationship between the individual and the collective. Through orientation training, thematic education, regular ideological education, national defense education, etc., we should help them establish a Marxist world outlook on life and values. The relationship between the individual and the political party, the individual and the army should be viewed correctly. Correctly grasp the dialectical relationship between freedom and discipline, democracy and centralism, dedication and demand. In this way, we will consciously abide by the military's political discipline, rules and regulations, constantly strengthen our ideological line of defense, and temper our strong political character, so as not to give the hostile forces any opportunity to westernize, divide, corrupt or draw in. 


\section{THE PRINCIPLE OF CONSTRUCTING THE MODEL OF POLITICAL VALUE SYSTEM OF MILITARY CIVILIAN PERSONNEL IN THE NEW ERA}

The system model of military civilian personnel's political values in the new era is to classify, design, select and cultivate the content and abstract the results according to certain methods and rules [3]. In order to build a more specific and targeted model of the political value system of military civilian personnel in the new era, it is necessary to follow the clear principles of model building. In the new era, the construction of the military civilian personnel's political value system model should embody the three principles: the nature and function of the people's army, respect the law of value formation, and be close to the professional practice.

\subsection{The principle of reflecting the nature and functions of the people's army}

Cultivating the political values of military civilian personnel aims to help those targeted develop strong political beliefs, firmly establish the purpose of serving the people, and firmly fulfill the functions and missions of the new era, In essence, it is necessary for civilian personnel to establish a political value orientation that conforms to the requirements of the party and the people, and its ultimate purpose is to guide and standardize the political behavior of civilian personnel, so as to lay an ideological foundation and provide spiritual impetus for them to perform their duties and missions.

The political values of military civilian personnel are closely related to the nature, purpose, mission and tasks of the people's army. The nature and purpose of the people's army define the political belief of the political values of the military civilian personnel, and the mission of the army answers the political requirements and practical paths of the military civilian personnel's political values. The military civilian personnel's political value system model can only fully reflect the military's nature, purpose, function, mission and specific requirements, cultivation can be targeted to provide practical focus, on the contrary, if the model of political value system lacks specific political requirements in this aspect, will be divorced from reality, lack of guiding significance.

\subsection{Respect the principle that values form rules}

The political value system model of military civilian personnel is the sum of their political cognition, political emotion, political will and political behavior. It is the coordinate system for military political workers to carry out the cultivation work, and it is also tailored for military civilian personnel. It must follow the law of value formation and carry out scientific design. On the one hand, based on the research on the formation mechanism of political values, the content design should be carried out from the cognitive level, emotional level, volitional level and behavioral practice, so as to achieve the goal of gradually strengthening students' political values. On the other hand, while emphasizing the theoretical content of values, the content structure of knowledge and skills, processes and methods is also needed to include the contents that have an important impact on the psychological and behavioral levels.

\subsection{Close to the quantifiable principle of professional practice}

If a theoretical model cannot be measured mathematically, it cannot be called rigorous. Therefore, the military civilian personnel's political value system model should be measurable in theory. In other words, the system model should present indicators that can be calculated and measured directly or indirectly. Many dimensions of political values may seem unidentifiable, but as long as they are close to the professional practices of civil servants, finding the right element index, using the right method that can achieve measurement. This principle requires us to fully consider the computability and measurability when constructing the military civilian personnel political value system model.

\section{THE CONSTRUCTION METHOD OF POLITICAL VALUE SYSTEM MODEL FOR MILITARY CIVILIAN PERSONNEL IN THE NEW ERA}

Model building method refers to the way the model is used and referenced in the construction process. General social science modelling can be carried out by questionnaire survey, literature statistics, factor analysis, network survey, etc. In this paper, the research group starts from two methods of PDU model extraction and literature statistics, and starts to build a political value system model for military civilian personnel in the new era.

\subsection{PDU model extraction}

Hugh Davidson, a scholar of corporate culture, argues that six practical steps are necessary to develop a set of values: the first step is to establish real values; the second step is to identify the key success factors of the organization; the third step is to follow the established ideal and identify the values that will drive it; the fourth step is to form the embryonic values to support the key success factors and goals, the fifth step puts forward the rudiment of values and the extensive discussion of subordinates. Finally, it supports the refinement and renewal of values in the same way after gaining wide recognition. Based on this idea, the corporate culture research office of the joint publicity committee of Chinese enterprises proposed the procedure of constructing the corporate values model based on years of research on 
Chinese enterprises.1As shown below:

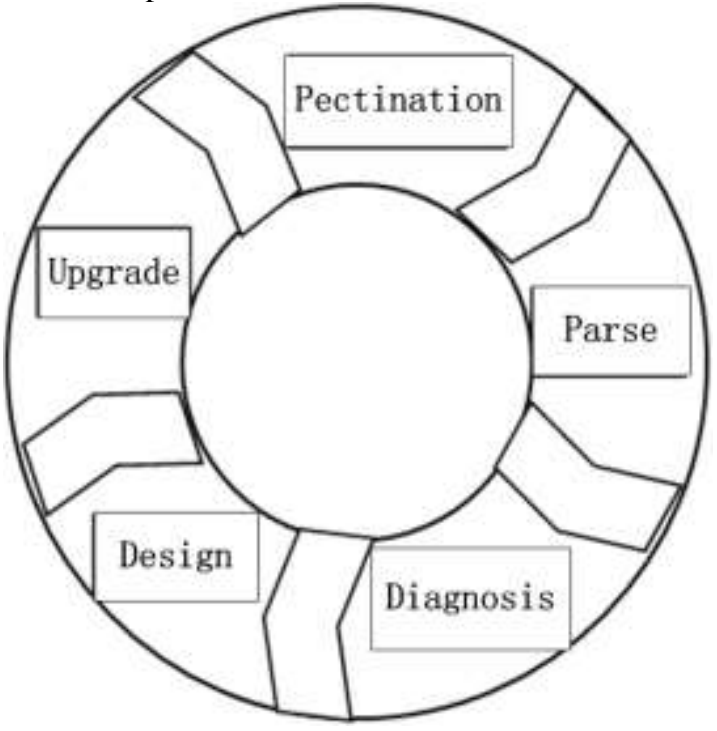

Figure 1 A PDU model extraction method for constructing the value system model

Pectination: sort the development of corporate culture

Parse: analyze corporate culture gene bank

Diagnosis: diagnose enterprise culture power index

Design: design values and value systems that align with vision, mission, and strategy

Upgrade: based on the evaluation results, change and upgrade the existing values

Accordingly, the PDU model extraction method can provide reference for the establishment of the military civilian personnel's political values model in the new era.
Combining the tradition and advantage of our army's political construction, we should follow the way of "sort out the development of military political culture-analyze the genetic factors that influence the military and political culture in the long history-diagnose environmental, political and cultural influence within the barracks-design a content system of military civilian personnel's political values consistent with the military strategy, functions and missions, and military strategies-based on the evaluation results, improve and upgrade the existing value system" and construct the political value system model of civilian personnel in the army in the new era.

\subsection{Literature statistics}

The so-called literature statistics method, that is, through the collection and investigation of various literature, to obtain information related to the subject. The advantage of this method is that it can obtain highly relevant information from a large number of literature in a relatively short period of time. For example, we can learn about the construction of the political values of the military youth groups, including the military civilian personnel. For example, we can learn about the construction of the political values of the young people in the military, including the civilian personnel, and provide important support and reference for the model construction in a more intuitive and efficient way. For example, search the Internet famous database respectively for keywords -"firm faith", "follow the command of the Part", "make a strong fight for war", "professional dedication". The results are shown in the following table1:

Table 1 Literature statistic results

\begin{tabular}{|c|c|c|c|c|c|c|c|c|c|c|c|c|c|c|}
\hline \multirow[b]{2}{*}{ Key words } & \multicolumn{4}{|c|}{$\begin{array}{l}\text { Wanfang Conference/Journal full text } \\
\text { database }(2000-2019)\end{array}$} & \multicolumn{4}{|c|}{$\begin{array}{l}\text { China Science and Technology } \\
\text { Journal Database }(2000-2019)\end{array}$} & \multicolumn{5}{|c|}{$\begin{array}{c}\text { CNKI } \\
(2000-2019)\end{array}$} & \multirow[t]{2}{*}{$\begin{array}{l}\text { A total of the } \\
\text { literature }\end{array}$} \\
\hline & $\begin{array}{c}\text { Dissertati } \\
\text { on }\end{array}$ & $\begin{array}{l}\text { journal } \\
\text { articles }\end{array}$ & $\begin{array}{l}\text { Conferen } \\
\text { ce } \\
\text { papers }\end{array}$ & $\begin{array}{l}\text { Literature } \\
\text { combined }\end{array}$ & $\begin{array}{c}\text { Dissert } \\
\text { ation }\end{array}$ & $\begin{array}{c}\text { journa } \\
1 \\
\text { article } \\
\mathrm{s}\end{array}$ & $\begin{array}{c}\text { Confer } \\
\text { ence } \\
\text { papers }\end{array}$ & $\begin{array}{c}\text { Literature } \\
\text { Combine } \\
\mathrm{d}\end{array}$ & $\begin{array}{c}\text { Dissert } \\
\text { ation }\end{array}$ & $\begin{array}{l}\text { journal } \\
\text { articles }\end{array}$ & $\begin{array}{c}\text { confere } \\
\text { nce } \\
\text { papers }\end{array}$ & $\begin{array}{c}\text { newspap } \\
\text { ers }\end{array}$ & $\begin{array}{c}\text { Literatur } \\
\text { e } \\
\text { combine } \\
\text { d }\end{array}$ & \\
\hline $\begin{array}{l}\text { firm } \\
\text { faith }\end{array}$ & 153 & 6835 & 60 & 7048 & 0 & 41 & 0 & 41 & 50 & 365 & 13 & 250 & 681 & \\
\hline $\begin{array}{l}\text { follow the } \\
\text { command of } \\
\text { the Party }\end{array}$ & 75 & 1566 & 13 & 1654 & 0 & 196 & 0 & 196 & 23 & 758 & 7 & 710 & 1504 & \\
\hline
\end{tabular}




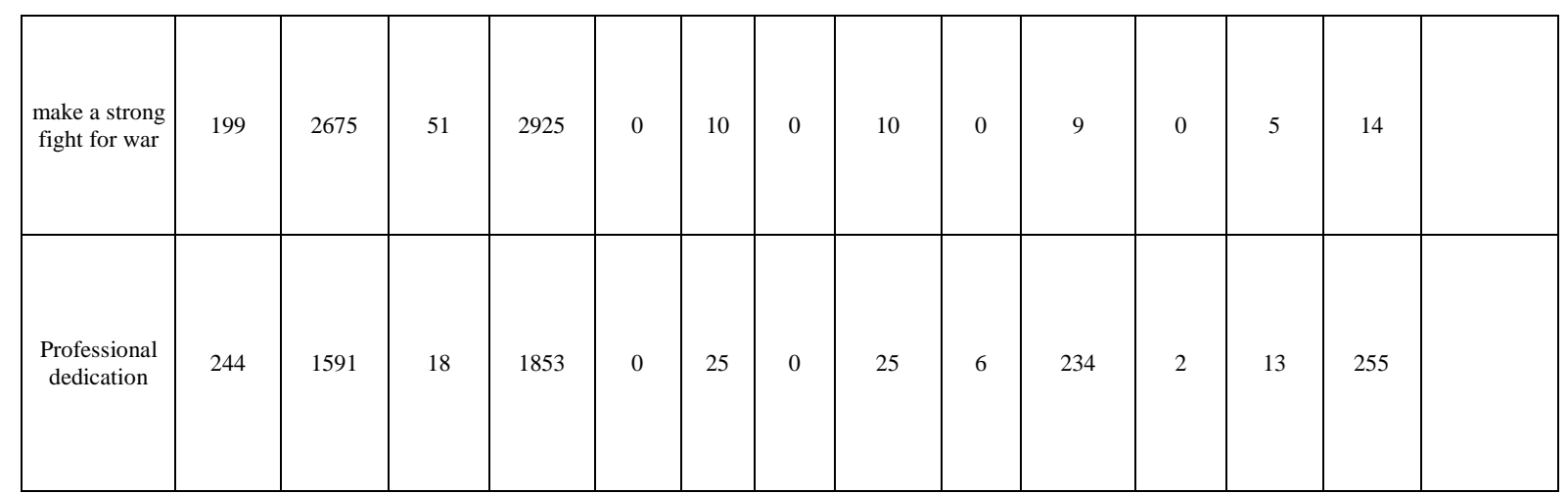

On this basis, narrow the search scope, on the basis of four aspects plus space + "structure", space + "dimension" in the

above database to continue to search, search results are shown in the figure of table2:

Table 2 Literature statistic results

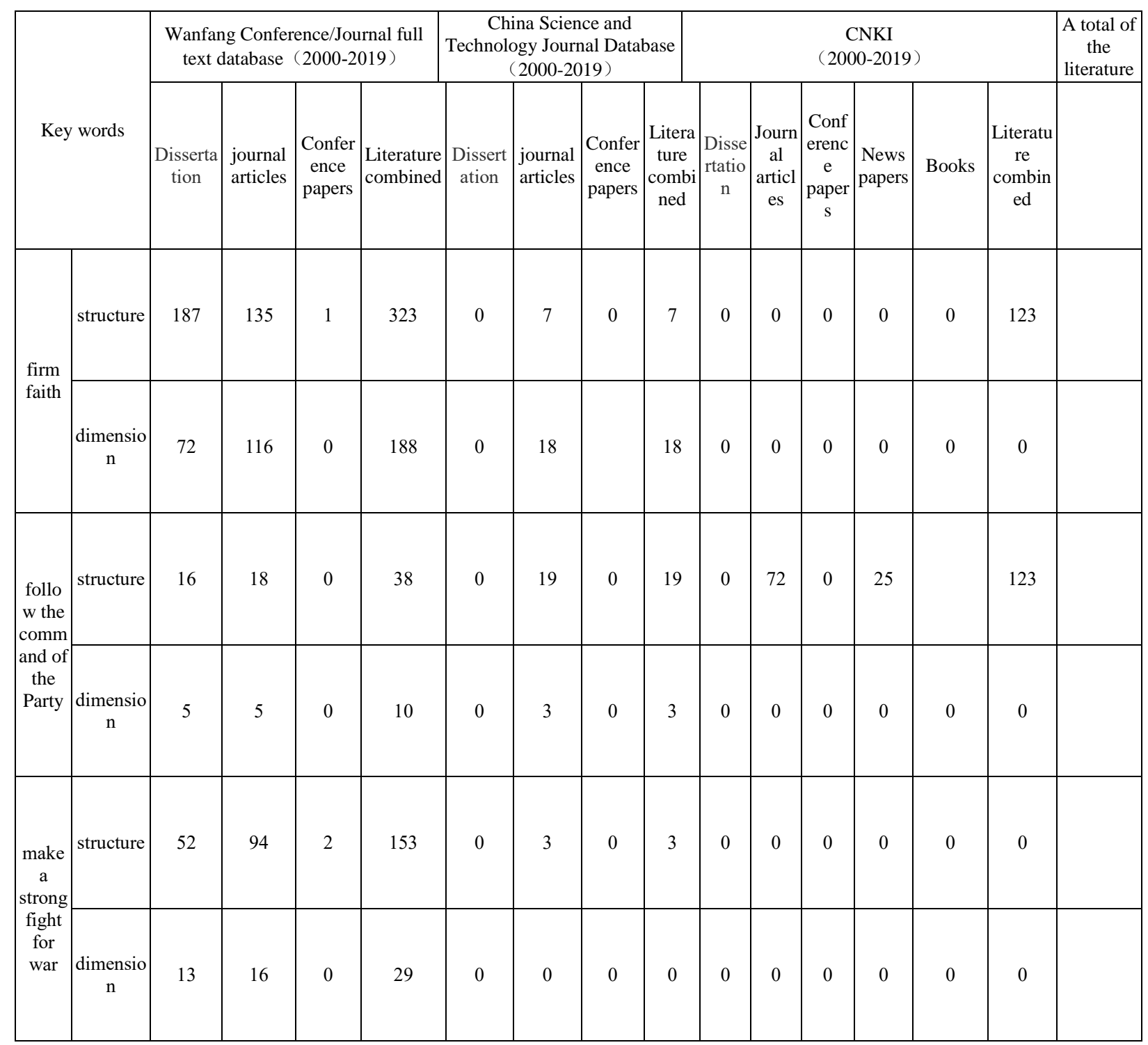




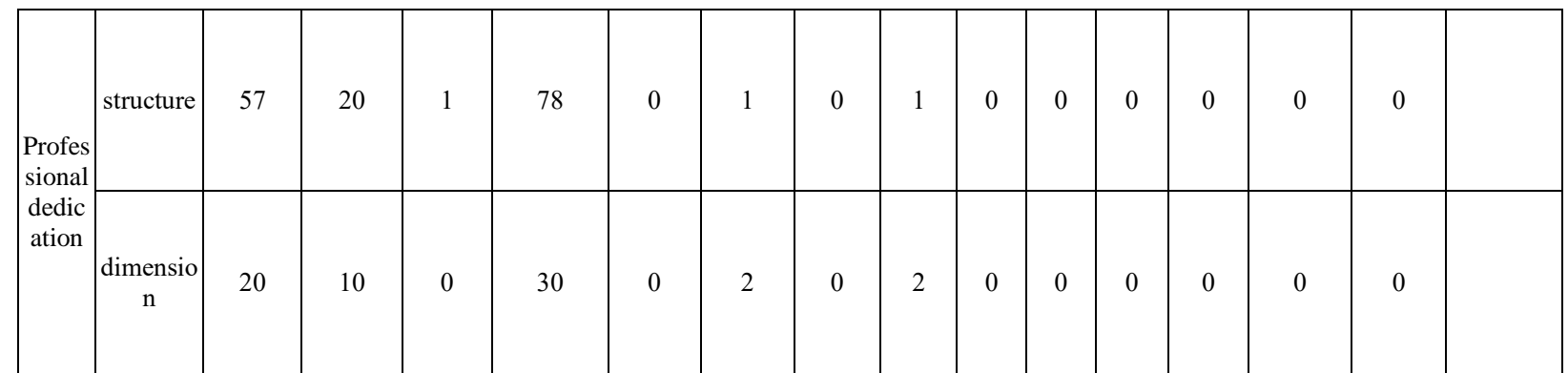

Through an in-depth analysis of the above search results, we can find that currently there are more studies on political values, more published results, and more overlapping information among databases. Based on this data, in the academic articles and works focusing on the four key words with high relevance or citation frequency, 79 relevant literature were analyzed in depth, and 26 words describing these key words were counted, as shown in the figure below table3:

Table 3 Literature statistic results

\begin{tabular}{|c|c|c|c|c|c|c|c|c|c|c|c|}
\hline $\begin{array}{c}\text { Key } \\
\text { words }\end{array}$ & $\begin{array}{c}\text { Relative } \\
\text { words }\end{array}$ & $\begin{array}{c}\text { Freque } \\
\text { ncy }\end{array}$ & Key words & $\begin{array}{l}\text { Relative } \\
\text { words }\end{array}$ & $\begin{array}{c}\text { Frequen } \\
\text { cy }\end{array}$ & $\begin{array}{c}\text { Key } \\
\text { words }\end{array}$ & $\begin{array}{l}\text { Relative } \\
\text { words }\end{array}$ & $\begin{array}{l}\text { Frequ } \\
\text { ency }\end{array}$ & Key words & $\begin{array}{c}\text { Relative } \\
\text { words }\end{array}$ & $\begin{array}{l}\text { Frequ } \\
\text { ency }\end{array}$ \\
\hline \multirow{6}{*}{ irm faith } & $\begin{array}{c}\text { Marxis } \\
\mathrm{m}\end{array}$ & 157 & \multirow{6}{*}{$\begin{array}{l}\text { follow the } \\
\text { command } \\
\text { of the Part }\end{array}$} & $\begin{array}{c}\text { the soul of } \\
\text { consciousne } \\
\text { ss }\end{array}$ & 97 & \multirow{6}{*}{$\begin{array}{l}\text { make a } \\
\text { strong } \\
\text { fight for } \\
\text { war }\end{array}$} & $\begin{array}{l}\text { successfully } \\
\text { accomplish } \\
\text { their mission }\end{array}$ & 34 & \multirow{6}{*}{$\begin{array}{l}\text { professiona } \\
1 \text { dedication }\end{array}$} & work hard & 31 \\
\hline & $\begin{array}{c}\text { Commu } \\
\text { nism }\end{array}$ & 98 & & $\begin{array}{c}\text { the CMC } \\
\text { chairman } \\
\text { assumes } \\
\text { overall } \\
\text { responsibilit } \\
\text { y }\end{array}$ & 21 & & $\begin{array}{c}\text { assuming } \\
\text { responsibilit } \\
\mathrm{y}\end{array}$ & 31 & & do duties & 32 \\
\hline & $\begin{array}{c}\text { Political } \\
\text { beliefs }\end{array}$ & 94 & & $\begin{array}{l}\text { follow the } \\
\text { Party }\end{array}$ & 17 & & Job training & 27 & & $\begin{array}{c}\text { Cherish } \\
\text { posts and } \\
\text { devote to } \\
\text { work }\end{array}$ & 24 \\
\hline & $\begin{array}{c}\text { ideal fai } \\
\text { th }\end{array}$ & 78 & & $\begin{array}{c}\text { know the } \\
\text { party }\end{array}$ & 34 & & $\begin{array}{c}\text { Purposes of } \\
\text { the people's } \\
\text { army }\end{array}$ & 24 & & $\begin{array}{c}\text { professional } \\
\text { ethics }\end{array}$ & 13 \\
\hline & $\begin{array}{l}\text { stay true } \\
\text { to the } \\
\text { mission }\end{array}$ & 35 & & $\begin{array}{l}\text { trust in the } \\
\text { party }\end{array}$ & 27 & & $\begin{array}{c}\text { defending } \\
\text { unity }\end{array}$ & 29 & & $\begin{array}{c}\text { service } \\
\text { awareness }\end{array}$ & 11 \\
\hline & $\begin{array}{c}\text { patriotis } \\
\mathrm{m}\end{array}$ & 51 & & $\begin{array}{c}\text { love the } \\
\text { party }\end{array}$ & 36 & & \begin{tabular}{|} 
safeguarding \\
the core \\
interests of \\
China
\end{tabular} & 17 & & $\begin{array}{c}\text { Selfless } \\
\text { dedication }\end{array}$ & 57 \\
\hline
\end{tabular}




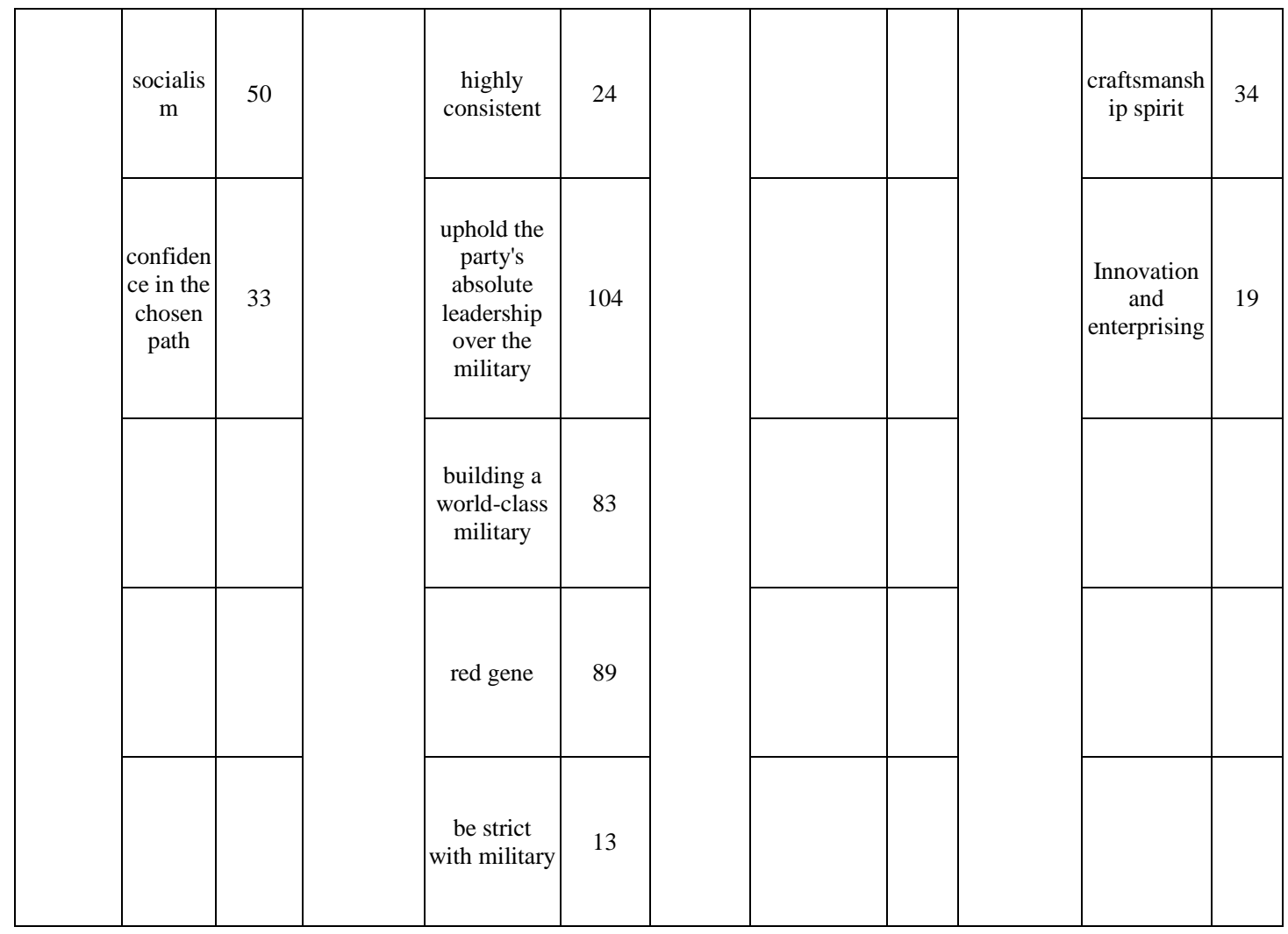

The data collected by literature analysis method to some extent shows the current academic understanding and grasp of the main components of military political values, which can be used as the framework for modelling.

\section{CONCLUSION: THE BASIC FRAMEWORK OF THE MODEL}

According to the PDU model extraction method, the research group combined the characteristics and advantages of the army's political construction. First of all, the political and cultural traditions of the military were carefully traced back to their origins. Then, it analyses the red genes that influence the military and political culture in the new democratic revolutionary war period, the socialist revolution and construction period, the reform and opening up period and the new socialist construction period, considering the influence of the internal environment of the barracks on the special political culture and political ecology. Finally, the content system of military civilian personnel's political values is designed with the core of "firm faith, follow the command of the Party, make a strong fight for war, professional dedication". It is worth noting that this system is open rather than static, and with the development of the times and the leap of the ideological and political quality of the civilian team, the new connotation of the times will be continuously injected.

Through the method of literature statistics, the research group made a careful study of the relevant elements and discussed with experts in the field of military political work many times. By means of the selection of topological structure and elements, the model structure of military civilian personnel's political value system is finally obtained and as shown below: 


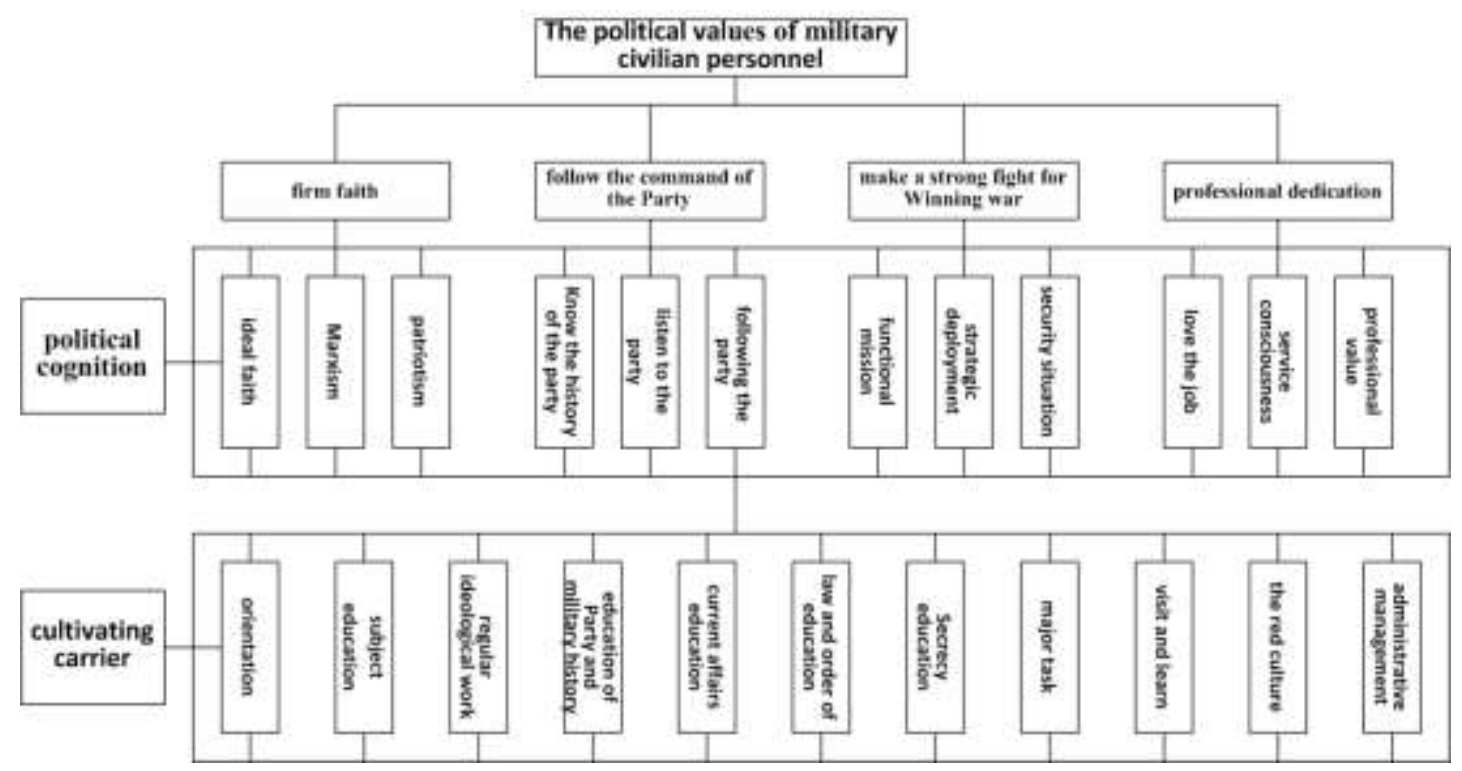

Figure 2 The political values of military civilian personnel

\section{ACKNOWLEDGMENT}

This paper is the phased achievement of 2019 national social science fund project "Study on the Ideological and Political Quality of Military Civilian Personnel in the New Era, Project number:19XGL028

\section{REFERENCES}

[1] Xi Jinping: On Faith and Belief[N], "People's Daily Overseas Edition", 2017-06-07(5)

[2] Xi Jinping: To Break New Ground in National Defense and Military Development in the Spirit of
Reform and Innovation, to Realize the Party's Goal of Building a Strong Army Under the New Situation[N], People's Daily, 2014-03-12(1).

[3] Zhu Tingchun. A Study on the Core Values of Contemporary Revolutionary Servicemen [M]. Beijing: National Defense University Press 2011 edition, 307: 137.

[4] Li Zhongjun. A Study on Ideological Security and Political Values of College Students [M], Shen Yang: Northeast Normal University press. The 2015 edition,351:58.

[5] Zhu Huiye, Cui Jiaying, Value Management[M], Beijing: Enterprise management press,2008 edition, Page 58. 